\title{
MIASTO PERMANENTNEJ MIGRACJI. KONCEPCJA AEROTROPOLII JOHNA KASARDY I JEJ SPOŁECZNE IMPLIKACJE
}

\begin{abstract}
Skoczylas Łukasz, Miasto permanentnej migracji. Koncepcja aerotropolii Johna Kasardy i jej społeczne implikacje [The city of permanent migration. The concept of aerotropolis by John Kasarda and its social implications] edited by J. Kubera, Ł. Skoczylas - "Człowiek i Społeczeństwo", vol. XXXVII, Poznań 2014, pp. 103-113, Adam Mickiewicz University Press. ISBN 978-83-232-2764-9. ISSN 0239-3271.

This paper presents the concept of the city-airport (aerotropolis) by John Kasarda. This concept is shown in the background of the development of air transport, the creation of large airport hubs and the contemporary processes of globalization. The article describes the advantages and disadvantages of the aerotropolis and shows the compounds of this concept with other theories of new forms of settlement and urbanism. The article presents the probable identity problems that may result from the creation of the city-airport. The text also discusses the chances of the creation of the aerotropolis in Poland.
\end{abstract}

Łukasz Skoczylas, Uniwersytet im. Adama Mickiewicza w Poznaniu, Instytut Socjologii, ul. Szamarzewskiego 89c, 60-568 Poznań, Poland.

\section{WSTĘP}

Miasto permanentnej migracji to typ idealny, trudny do wyróżnienia $\mathrm{w}$ realnym świecie. Globalizacja gospodarki i przemiany społeczno-polityczne sprawiają, że coraz więcej miast zbliża się do tego ideału. Z jednej strony są to miasta o stosunkowo krótkich dziejach w sensie wpływu światowego (np. Dubaj), z drugiej - takie, obok których wyrastają wielkie porty lotnicze, początkowo przeznaczone do obsługi lokalnej ludności, z czasem ewoluujące w kierunku globalnego transportu ruchu i towarów. Światowy ruch lotniczy coraz częściej obsługiwany jest przez największe lotniska, będące jednocześnie bazą dla linii lotniczych (tzw. huby). To pomiędzy nimi loty odbywają największe samoloty. Pasażerowie dopiero później, 
po przesiadce, przewożeni są mniejszymi maszynami na lotniska docelowe, których znaczenie ma bardziej lokalny wymiar. Ta tendencja, rzutująca na strategie koncernów budujących samoloty, staje się niezwykle ważna ze względu na zyski osiągane $\mathrm{z}$ transportu lotniczego. Największe linie konkurują nie tylko swoimi sieciami połączeń, lecz także hubami - ich atrakcyjnością, wielkością i bliskością głównych skupisk ludności. Ale hub to nie tylko wielkie centrum przesiadkowe dla ludzi - to również port przeładunkowy dla ogromnej liczby towarów. Powstawanie hubów wiąże się zapewne $\mathrm{z}$ rosnącą metropolizacją globalnej gospodarki i polityki, a więc pojawianiem się „węzłów globalnego zarządzania” (Michalska-Żyła 2010: 13-23). Istnienie wielkich metropolii, których kulturowe i ekonomiczne znaczenie ma zasięg światowy lub choćby kontynentalny, wymaga szybkiego i sprawnego transportu lotniczego, często bowiem to właśnie szybkość dostawy jest w metropoliach kwestią najważniejszą, na dalszy plan przesuwając jej koszty.

Wraz z rozwojem hubów, mniejszych lotnisk i całego transportu lotniczego coraz istotniejsze stają się społeczne skutki wzmożonej migracji, gdyż jest to migracja dotycząca przede wszystkim osób zamożnych lub przedstawicieli klasy średniej. Rośnie grono osób, dla których częste podróże samolotami stają się koniecznością $\mathrm{w}$ sensie zawodowym; styl życia dostępny niegdyś niemal wyłącznie pracownikom obsługi linii lotniczych, dziś staje się coraz powszechniejszy. Świat permanentnej migracji, oprócz swojego podmiejskiego oblicza osób codziennie dojeżdżających do dużego miasta $\mathrm{z}$ prowincji lub przedmieść, ujawnił $\mathrm{w}$ ostatnich dziesięcioleciach drugą postać: jest nim lotnisko jako przestrzenne centrum spotkań osób pozostających w niemal ciągłej podróży. Łączy się to z niezwykle ciekawymi procesami tożsamościowymi. $Z$ jednej strony bowiem ludzie tacy przemierzają ogromne przestrzenie, mając kontakt $\mathrm{z}$ wieloma kulturami. $\mathrm{Z}$ drugiej strony dużą część swojego życia spędzają w najczęściej podobnych do siebie pod względem funkcjonowania i wyglądu przestrzeniach lotniskowych. Innymi istotnymi kwestiami są dylematy związane $\mathrm{z}$ rozwojem lotnisk w kontekstach: urbanistycznym, ochrony przyrody, jakości życia pracowników oraz sąsiadów itd.

\section{KONCEPCJA AEROTROPOLII JOHNA KASARDY}

Jednym z badaczy zjawiska powstawania i funkcjonowania hubów lotniczych jest John Kasarda. Wieszczy on powstanie w przyszłości sieci globalnych hubów, które byłyby otoczone przez nowo powstałe miasta, skupione przede wszystkim na wytwórczości i usługach związanych 
z transportem towarów. Takie jednostki urbanistyczne, połączenie miasta z lotniskiem, nazywa aerotropoliami. Różnią się one od większości współczesnych lotnisk tym, że tworzone są najczęściej nie w celu obsługi już istniejących dużych aglomeracji, lecz na terenach relatywnie słabo zaludnionych, nieposiadających też rozbudowanej infrastruktury transportowej czy przemysłowej. Czasami są to dawne tereny wojskowe (w tym lotnisk wojskowych), czasem niemal całkowite pustkowia. Aerotropolie rozwijają się również wokół wielkich lotnisk powstałych z myślą o obsłudze dużych aglomeracji, które jednak geograficznie są od nich oddalone. Stanowią one centrum aktywności związanych zarówno z lotnictwem, jak i z każdym innym rodzajem ekonomicznego zaangażowania $\mathrm{w}$ gospodarkę (Johnston 2009). Ze względu na szybkość transportu zapewnianą przez lotnisko oraz wolność w zagospodarowywaniu terenu szybki rozwój aerotropolii wiąże się z budową fabryk, centrów obsługi i innych przedsiębiorstw o charakterze outsourcingowym, a ponadto obiektów targowych i ośrodków akademickich. Swoją książkę, mającą przybliżyć ideę aerotropolii szerszemu gronu czytelników, John Kasarda i Greg Lindsay rozpoczynają następującym mottem przewodnim: „Kształty i losy miast zawsze były definiowane przez transport. Dziś oznacza on podróże lotnicze" (Kasarda, Lindsay 2012: 3).

Współczesne lotniska, jak twierdzą owi autorzy, są nieodzownym elementem zglobalizowanego rynku, pozwalającego na szybkie przemieszczanie towarów i - przede wszystkim - na outsourcing produkcji. Wzrost znaczenia transportu lotniczego zawdzięczamy zapewne rozwojowi Internetu i usieciowieniu społeczeństwa oraz gospodarki. Wzrastająca szybkość przekazu danych wymaga wzrastającej szybkości przekazu rzeczy materialnych; stąd wynika uznanie lotnictwa za "fizyczny Internet” (Kasarda, Lindsay 2012: 176). Transport samolotowy, mimo że wciąż znacznie mniej rozwinięty od morskiego, jeśli chodzi o tonaż, przoduje w wartości przewożonych produktów i jest bardziej niezawodny (Kasarda, Lindsay 2012: 33). Dlatego lotnisko może przynosić ogromne zyski, nie tylko liczone $\mathrm{w}$ bezpośrednich wpływach do budżetu właścicieli czy organów podatkowych, lecz polegające przede wszystkim na tworzeniu nowych miejsc pracy.

Głównym problemem dla rozwoju lotnisk wydają się ruchy NIMBY (not in my back yard - nie w moim ogródku), a więc stowarzyszenia mieszkańców okolic planowanych lub istniejących lotnisk, które skupiają osoby niezadowolone z uciążliwego sąsiedztwa (Kasarda, Lindsay 2012: 29). Dość często uznaje się tego typu organizacje za przejaw współczesnej logiki gospodarczego funkcjonowania społeczeństw zachodnich, których członkowie za zasadne uznają budowanie obiektów usługowych lub przemysłowych o wielkim znaczeniu, jednak pod warunkiem, że nie będą one znajdowały 
się obok miejsca ich zamieszkania. Podobne działania podejmowane są przecież w przypadku elektrowni, oczyszczalni ścieków, wysypisk, sortowni śmieci itp. Ta sama zasada obowiązuje w przypadku inwestycji o charakterze społecznym, takich jak budowa ośrodka więziennego, szpitala psychiatrycznego czy schroniska dla osób bezdomnych. W sensie geograficznym powszechna akceptowalność dla takich inwestycji zatrzymuje się w okolicy, w której inwestycja ma być przeprowadzona - tam mają miejsce protesty i poczucie niezadowolenia z decyzji lokalizacyjnej. Jak piszą Kasarda i Lindsay (2012: 58), wielkie lotniska amerykańskie, takie jak LAX w Los Angeles, O’Hare w Chicago czy Dulles w Waszyngtonie, istnieją wbrew okolicznym metropoliom, a nie dzięki nim. Podobnych problemów nie mają jednak aerotropolie zakładane $\mathrm{w}$ odludnych obszarach, są elementem zastałym dla większości ludzi, którzy wraz z ich rozwojem postanawiają się w nich osiedlić.

Koncepcja aerotropolii jest niezwykle ciekawa, może się jednak wydawać nieco nierzeczywista. Tymczasem John Kasarda był konsultantem co najmniej kilku inwestycji, które można uznać za próbę stworzenia aerotropolii. Jedną z nich jest rejon przemysłowy North Carolina Global Transpark, inną - kompleks Subic Bay na Filipinach, gdzie strefę wolnego handlu wraz z lotniskiem stworzono na terenie dawnej bazy wojskowej. Ze względu na swoje malownicze położenie Subic Bay stało się również lokalną atrakcją turystyczną, odwiedzaną przez krajowych turystów. Kasarda współpracował także przy budowie lotniska Suvarnabhumi koło Bangkoku w Tajlandii (Kasarda, Lindsay 2012). Za aerotropolie uznaje się też lotnisko Schiphol w Amsterdamie, które otoczone jest wianuszkiem parków przemysłowych, a okoliczni mieszkańcy robią zakupy w publicznie dostępnej części terminalu, gdy inne sklepy są już zamknięte (Kasarda 2006), lotnisko Al Maktoum w Dubaju, międzynarodowe lotnisko w Memphis w Stanach Zjednoczonych (Shea 2008) czy też nowe lotnisko w Pekinie (Kasarda, Lindsay 2012). Obecnie autor opisywanej koncepcji współpracuje w tworzeniu aerotropolii w okolicy Detroit. Powstać ma tam centrum biznesowe obejmujące powierzchnią prawie 25 tys. hektarów, w tym dwa już istniejące lotniska. Realizację całego projektu zaplanowano na 25 lat - w tym czasie ma zostać utworzonych niemal 65 tys. miejsc pracy (Shea 2008). Ma to być ostatnia deska ratunku dla zrujnowanego Detroit, w którym wyburzane są całe kwartały zabudowy jako skutek ogromnego i wieloletniego odpływu ludności.

\section{SPOŁECZNE WYMIARY AEROTROPOLII}

Zyski wynikające z budowy aerotropolii wydają się ogromne. Skupmy się na chwilę na negatywnych aspektach tego nowego typu miasta. Pamiętać 
należy, że tak wielki twór, budowany od podstaw i mający efektywnie funkcjonować, wymaga również efektywnego zarządzania. Ta teza to jedna z najczęściej powtarzanych w książce Kasardy i Lindsaya. Autorzy sami zauważają, iż w standardowych warunkach jest to rzecz niezwykle trudna do zrealizowania ze względu na różnorodność podmiotów, które miałyby istnieć $\mathrm{w}$ ramach jednego organizmu - od lotniska, poprzez prywatne firmy, magazyny, infrastrukturę przeładunkową, ośrodki akademickie, po dzielnice mieszkalne i związane z nimi obiekty użyteczności publicznej. Stąd też Kasarda i Lindsay (2012: 246) sami przyznają, iż najbardziej wydajne w tworzeniu aerotropolii są władze o charakterze autorytarnym.

Kolejnym problemem, na który zwracają uwagę autorzy, nieco go jednak bagatelizując, jest uzależnienie nowego tworu miejskiego od lotniska (Kasarda, Lindsay 2012: 181). Przypomina on bowiem industrialne miasta, tworzone wokół zakładów przemysłowych, które - wraz z upadkiem fabryk lub ich coraz dalej idącą robotyzacją - zaczęły się borykać z problemem rosnącego bezrobocia. W przypadku małych miast przypomnieć należy wstrząsający przykład austriackiego Marienthalu, badanego w latach wielkiego kryzysu przez zespół Marie Jahody, Paula Lazarsfelda i Hansa Zeisela (2007). Gdybyśmy uznali, że aerotropolia może rozrosnąć się do znacznie większych rozmiarów, to możemy przywołać przykład współczesnego Detroit. Kasarda i Lindsay (2012: 181), opisując uzależnienie amerykańskiej aglomeracji od przemysłu motoryzacyjnego, używają w kontekście Detroit określenia „autotropolia”. I choć wedle założeń miasto-lotnisko ma być centrum wielu inicjatyw gospodarczych i naukowych, nietrudno wyobrazić sobie tragiczne w skutkach zmiany, jakim podlegałaby cała okolica, gdyby zbankrutowały największe ze znajdujących się tam firm lub gdyby miejscowe lotnisko przestało być ekonomicznie opłacalne. Podstawowym zagrożeniem dla przyszłości aerotropolii wydaje się fakt, iż jego koncepcja i sens istnienia zawierają się w ekonomicznych korzyściach. Tymczasem ściśle ekonomiczne pojmowanie natury człowieka redukuje jego złożoność do czystej racjonalności, co w urbanistyce i projektowaniu architektonicznym prowadzi do mnóstwa błędów i ostatecznie tworzy środowisko niesatysfakcjonujące dla wielu jego użytkowników (Bańka 1997: 41).

Ciekawą kwestią pozostaje, na ile aerotropolia mogłaby funkcjonować jako satysfakcjonujące miejsce pracy i życia w sensie poczucia przynależności, czy też związku psychicznego z takim miejscem. Dla francuskiego etnologa i antropologa kulturowego Marca Augé (2010) współczesne lotnisko jest nie-miejscem. Jest więc pozbawione swojego własnego genius loci; nie może stać się podstawą czyjegoś poczucia przynależności, gdyż z zasady 
znajduje się poza konwencjonalnie rozumianą przestrzenią i czasem. Lotnisko jest bowiem strefą przejściową, w której krążą pasażerowie z różnych miejsc, poddający się jednej i zrozumiałej na całym świecie logice działań, $\mathrm{z}$ jednej strony jasno zdefiniowani w stosunku do władzy (mają wszak przy sobie dokumenty tożsamości), $\mathrm{z}$ drugiej zaś - niemal zupełnie anonimowi wobec siebie nawzajem. Czy miejsce takie mogłoby stać się centrum nowego miasta? Tradycyjne centrum miasta zachodniego kręgu kulturowego składa się najczęściej z miejsc o długich dziejach, wykorzystywanych w tożsamościowej narracji jego mieszkańców. W aerotropolii centrum takim byłoby nie-miejsce, wybudowane wedle powszechnego wzoru (nawet jeśli zawierającego pewne wyjątkowe elementy), skupione na obsłudze podróżnych niezainteresowanych samym miastem, lecz tylko podróżą lub konkretną sprawą, jaką $w$ aerotropolii mają do załatwienia. Sytuacja taka wydaje się niezwykle trudna dla mieszkańców. Problemy w konstruowaniu tożsamości w aerotropolii można prawdopodobnie porównać z trudnościami mieszkańców wielkich modernistycznych osiedli - być może interesujących w sensie estetycznym, ale pozbawionych charakterystycznych punktów orientacyjnych, łudząco do siebie podobnych, wzmacniających poczucie anonimowości i wyobcowania. Świat, którego sensem istnienia jest migracja ludzi i transport towarów, musi stanowić wyzwanie dla psychicznego dobrostanu jednostki i jej społecznego funkcjonowania. Są oczywiście liczne miasta, których centra zbudowane zostały we współczesnych formach, np. po zniszczeniach wojennych. Jednak nawet wtedy były one tworzone $\mathrm{z}$ myślą o aktywności kulturalno-rekreacyjnej mieszkańców. Aerotropolia przypomina bardziej, jak już wcześniej wspominaliśmy, miasto przemysłowe lub handlowe $\mathrm{z}$ dalekiej przeszłości, np. $\mathrm{z}$ okresu rewolucji industrialnej. Tymczasem, jak twierdzi Aleksander Hauziński (2010: 368), „Przywiązanie do miejsca może stanowić wskaźnik swoistej efektywności społecznej, kompetencji sprzyjającej poznaniu i zrozumieniu norm i wartości własnej i obcej kultury. Ma ono tym większe znaczenie, że coraz wyższy procent pracowników i osób poszukujących pracy kontaktuje się z przedstawicielami innych kultur - bezpośrednio w kontaktach «twarzą w twarz» i pośrednio, socjalizując normy i czynniki kultury oraz klimat organizacji o charakterze międzynarodowym i globalnym". Za takim stwierdzeniem kryje się przekonanie o większej otwartości na odmienność, jaką charakteryzują się osoby o konkretnym i względnie stałym poczuciu tożsamości indywidualnej oraz zbiorowej. Choć można się z tą opinią nie zgadzać, jej przyjęcie musi nas skłonić do wniosku, że - paradoksalnie - aerotropolia może utrudniać satysfakcjonujące kontakty międzykulturowe. 


\section{MIASTO KRAŃCOWE}

Aerotropolię można uznać za przykład edge city, czyli miasta krańcowego (Nieszczerzewska 2005). To popularne w Stanach Zjednoczonych określenie odnosi się do jednostek miejskich położonych z dala od dawnych centrów miast i pozbawionych własnego centrum $\mathrm{w}$ sensie kulturowo-ekonomicznym. Edge city to miasto "rozlane”, żyjące wokół skupisk biurowców lub (rzadziej) fabryk. Zawiera w sobie wszystkie funkcje spełniane przez tradycyjne miasta, ale w mniej zwartej formie (McCann 2009). Powstawanie tego typu jednostek miejskich sprzyja rozbiciu urbanistycznemu i towarzyszy postępującemu upadkowi tradycyjnych miast przemysłowych, w naturalny sposób wysysając $\mathrm{z}$ nich osoby $\mathrm{w}$ wieku produkcyjnym i tzw. klasę kreatywną. Autorem koncepcji edge city jest Joel Garreau (McCann 2009). Sama teza o istnieniu tego typu skupisk ludzkich nie jest wyjątkowa oprócz "edge city" używano również takich określeń, jak „technomieścia”, „miejskie wioski" czy „miasta obwodowe” (Cannato 1992) - a całą koncepcję uznawano już za "dziennikarską interpretację" (Lee 2007: 479). Nie ulega jednak wątpliwości, że zjawisko to jest obecne we współczesnych procesach urbanistycznych, i to nie tylko w Stanach Zjednoczonych - przykłady europejskie pochodzą między innymi $\mathrm{z}$ aglomeracji paryskiej czy konurbacji Randstad w Holandii, ale także z aglomeracji budapeszteńskiej czy berlińskiej (Bontje, Burdack 2005). Choć istnienie lotniska jest sensem istnienia aerotropolii, trudno jednak uznać je za centrum w kulturowym, społecznym czy nawet ekonomicznym tego słowa znaczeniu. O ile lotnisko jest najważniejszym elementem gospodarki całego miasta, to przecież nie jest ono miejscem produkcji ani negocjacji handlowych, nie tutaj mieszczą się call-centre i biura projektowe. Dlatego też, mimo istnienia geograficznego centrum aerotropolii, $\mathrm{w}$ sensie społecznym jest ona miastem rozczłonkowanym, skupionym wokół wielu biurowców, centrów handlowych, obiektów sportowych itd. (plan przykładowej aerotropolii można obejrzeć na stronie internetowej Johna Kasardy (Kasarda 2013)). Zresztą sam Garreau (1994) z zaskoczeniem zwraca uwagę na fakt, że część edge cities rozwinęła się wokół ogromnych lotnisk, obsługujących wielkie metropolie, takie jak wspomniane wyżej LAX w Los Angeles czy międzynarodowy port lotniczy w Miami na Florydzie.

Garreau przekonuje, iż edge cities są atrakcyjnym miejscem do życia i jeśli uznamy aerotropolię za odmianę miasta krańcowego, to również tutaj życie powinno być wygodne i bezpieczne. Miasta krańcowe są silnie sfeminizowane, jest tam dużo więcej dzieci niż przeciętnie, ludność cieszy się niskim poziomem przestępczości, wyższymi dochodami, a zróżnicowanie etniczne 
i rasowe jest nieporównywalnie większe niż na tradycyjnych przedmieściach, zarezerwowanych przede wszystkim dla białych (Garreau 1994).

W państwach wysokorozwiniętych aerotropolie skupiają zapewne przede wszystkim wysoko wykwalifikowaną siłę roboczą, tzw. klasę kreatywną. W przypadku państw rozwijających się mieszkańcami są prawdopodobnie pracownicy usług i robotnicy przemysłowi. Ta różnica może być istotna, jeśli próbujemy patrzeć na aerotropolię jak na miasto krańcowe, charakterystyczne dla krajów bogatych - Stanów Zjednoczonych czy państw Europy Zachodniej (próby wyróżnienia edge city w okolicach Moskwy nie powiodły się) (Bontje, Burdack 2005). Innymi słowy, część zalet miast krańcowych może wynikać ze stanu gospodarki krajów, w których są one tworzone, nie zaś ze sposobu ich organizacji lub funkcjonowania.

\section{AEROTROPOLIA W POLSCE?}

Powstanie aerotropolii związane jest $\mathrm{z}$ postępującą metropolizacją globalnej gospodarki oraz ruchów migracyjnych. To nie konkretne państwa, lecz miasta stają się punktami docelowymi dla różnych rodzajów migracji; miasta pełnią coraz ważniejszą rolę w życiu politycznym świata, w głównych miastach mieszczą się siedziby wielkich korporacji, których decyzje wpływają na stan globalnej gospodarki itd. Metropolizacja jest jedną z najważniejszych przyczyn powstania aerotropolii jako idei i jako gospodarczej potrzeby. Tymczasem brak jest w Polsce metropolii o światowym czy choćby kontynentalnym znaczeniu. Biorąc pod uwagę liczbę ludności, co najmniej kilka polskich miast mogłoby pełnić funkcję choćby kontynentalnych metropolii, wyspecjalizowanych w jakimś konkretnym rodzaju działalności i z tego względu mających ponadnarodowe znaczenie. A jednak ani siła ekonomiczna, ani kulturowa siła przyciągania nie mogą stać się podstawą budowania metropolitarnej pozycji dla żadnego z polskich miast. Dzieje się tak mimo dużych ambicji, których odzwierciedleniem jest choćby budowanie kolejnych międzynarodowych lotnisk. Obecnie istnieje w Polsce 13 cywilnych portów lotniczych obsługujących ruch pasażerski (Warszawa Okęcie, Warszawa Modlin, Kraków Balice, Gdańsk Rębiechowo, Katowice Pyrzowice, Wrocław Starachowice, Poznań Ławica, Rzeszów Jasionka, Łódź Lublinek, Szczecin Goleniów, Bydgoszcz Szwederowo, Zielona Góra Babimost, Lublin Świdnik), dwa kolejne - Gdynia Kosakowo i Radom Sadków są $\mathrm{w}$ trakcie budowy; niepewny jest status lotniska Szczytno Szymany w województwie warmińsko-mazurskim. Spora część istniejących portów przeszła $\mathrm{w}$ ostatnich latach poważne przebudowy $\mathrm{i}$ jest przystosowana do 
obsługi znacznie większej liczby pasażerów, niż w rzeczywistości obsługuje. Najciekawsza w tym kontekście wydaje się przebudowa warszawskiego portu im. Fryderyka Chopina. Do starszego terminalu, którego postmodernistyczna bryła wywoływała skojarzenia ze stylem zakopiańskim $\mathrm{w}$ architekturze, dobudowano nowocześniejszy i pozbawiony jakichkolwiek narodowych odniesień nowy terminal. W roku 2012 rozpoczęto przebudowę starszego obiektu tak, aby architektonicznie dopasować go do nowszego. Prace powinny zostać ukończone pod koniec 2014 r. Budowla, która swoją formą wspierała lokalną tożsamość, została w stolicy Polski zastąpiona kolejnym na świecie terminalem o charakterze nie-miejsca.

Jedyną prawdopodobnie możliwością powstania w Polsce aerotropolii, opartej nie tylko na wąsko rozumianym przemyśle wytwórczym, byłaby budowa dużego lotniska w zachodniej Polsce, obsługującego jednocześnie: województwo lubuskie, zachodnią i centralną część Wielkopolski z Poznaniem oraz niemiecką aglomerację Berlina. Istotny jest tu brak znaczących barier geograficznych i stosunkowo dobrze rozwinięta sieć drogowa łącząca te obszary. Z powodu istnienia barier i słabej infrastruktury drogowej mało prawdopodobne jest szerokie oddziaływanie dużego lotniska w teoretycznie podobnych regionach kraju, np. w okolicy Krakowa. Niestety, projekt aerotropolii na zachodzie kraju wydaje się mało prawdopodobny ze względu na budowę lotniska Berlin Brandenburg, którego oferta skierowana jest również do mieszkańców Polski i polskich firm. $Z$ tego też powodu większy potencjał dla powstania polskiej aerotropolii mają projekty wsparcia mniej rozwiniętych obszarów kraju, w których budowa lotniska byłaby bardziej opłacalna niż budowa wydajnej sieci drogowej. Taka aerotropolia miałaby najpewniej ścisły związek z powstaniem fabryk i miejsc pracy niewymagających wysoko wykwalifikowanej siły roboczej. Byłaby więc to raczej aerotropolia na wzór państw rozwijających się, nie zaś rozwiniętych. Ze względu na geograficzną bliskość chłonnych rynków europejskich perspektywy tworzenia tego typu lotnisk w Polsce są, jak można sądzić, nikłe, także zważywszy na wysoką konkurencyjność transportu drogowego. Stąd też najbardziej rozsądną ewentualnością wydaje się powstanie aerotropolii mogącej wypełniać do pewnego stopnia obydwa opisane wyżej sposoby funkcjonowania - z jednej strony stanowić ofertę dla dużej aglomeracji, z drugiej - dla ulokowanych w pobliżu firm. Tego typu ośrodek mógłby powstać w okolicy każdego dużego polskiego miasta, choć oczywiście za najbardziej dogodne lokalizacje należy uznać okolice największych skupisk ludności w kraju, a więc konurbacji górnośląskiej i aglomeracji warszawskiej. Szczególnie ta druga, wobec powstania lotniska w Modlinie, wydaje się ciekawym miejscem dla rozwoju aerotropolii, jednak istnienie i ciągle trwająca rozbudowa 
drugiego warszawskiego lotniska może być - paradoksalnie - znacznym utrudnieniem dla tego typu inwestycji. Brak silnego przewoźnika mającego swoje główne bazy w Polsce również znacząco utrudnia stworzenie w naszym kraju prężnego hubu dla przewozów pasażerskich.

Mówiąc o ewentualności powstania polskiej aerotropolii, należy zwrócić uwagę na fakt, że polska myśl planistyczna odeszła daleko od wielkich projektów urbanistycznych. Myślenie kategoriami ogólnokrajowymi w urbanistyce charakterystyczne jest dla okresu Polskiej Rzeczypospolitej Ludowej, kiedy to nowo powstające miasta były elementami planu gospodarczego obejmującego całość państwa (Paszkowski 2011: 244-247), a jednocześnie stanowiły odzwierciedlenie obowiązującej doktryny ekonomiczno-społecznej. Tymczasem aerotropolia jako węzeł transportowy i centrum rozwoju ekonomicznego siłą rzeczy stanowi przejaw myślenia i planowania w kategoriach wieloletnich i ogólnokrajowych.

Trudno zatem przewidzieć szanse na powstanie w Polsce miasta permanentnej migracji lub ośrodka choćby zbliżającego się do tego typu. Z różnych przyczyn - ekonomicznych, politycznych i społecznych - aerotropolia wydaje się bytem $w$ Polsce niemożliwym. Warto jednak bacznie przyglądać się losom tego typu miast $\mathrm{w}$ innych częściach świata, ponieważ ich pojawienie się i rozwój to wyraz postępujących procesów globalizacyjnych, którym podlegamy także w Polsce. Niezależnie od tego, na ile trafna jest koncepcja aerotropolii Johna Kasardy, rosnące znaczenie transportu lotniczego pozostaje niezaprzeczalnym faktem.

\section{BIBLIOGRAFIA}

Augé M. (2010), Nie-miejsca. Wprowadzenie do antropologii hipernowoczesności, Wydawnictwo Naukowe PWN, Warszawa.

Bańka A. (1997), Architektura psychologicznej przestrzeni życia. Behawioralne podstawy projektowania, Gemini, Poznań.

Bontje M., Burdack J. (2005), Edge cities, European style: Examples from Paris and Randstad, "Cities" vol. 22, no. 4.

Cannato V.J. (1992), Cities on the edge, „Public Interest” no. 107.

Garreau J. (1994), Edge cities, „American Demographics” vol. 16, no. 2.

Hauziński A. (2010), Zjawisko przywiazania do miejsca jako składnik poczucia tożsamości, [w:] Jakość wobec wyzwań XXI wieku, red. N. Majchrzak, A. Zduniak, Wydawnictwo Wyższej Szkoły Bezpieczeństwa, Poznań.

Jahoda M., Lazarsfeld P.F., Zeisel H. (2007), Bezrobotni Marienthalu, Oficyna Naukowa, Warszawa.

Johnston R. (2009), Aerotropolis, [w:] Dictionary of Human Geography, eds D. Gregory, R. Johnston, G. Pratt, M.J. Watts, S. Whatmore, Wiley-Blackwell, Hoboken.

Kasarda J. (2006), Airports now not about the planes, „The Courier Mail” 2.07.2006. 
Kasarda J. (2013), Aerotropolis, strona internetowa Johna Kasardy, http://www.aero tropolis.com/ [dostęp: 16.10.2013].

Kasarda J., Lindsay G. (2012), Aerotropolis. The way we'll live next, Penguin Books, London. Lee B. (2007), "Edge” or "edgeless” cities? Urban spatial structure in U.S. metropolitan areas, 1980 to 2000, ,Journal of Regional Science" vol. 47, no. 3.

McCann E. (2009), Edge city, [w:] Dictionary of Human Geography, eds D. Gregory, R. Johnston, G. Pratt, M.J. Watts, S. Whatmore, Wiley-Blackwell, Hoboken.

Michalska-Żyła A. (2010), Psychospołeczne więzi mieszkańców z miastem, Wydawnictwo Uniwersytetu Łódzkiego, Łódź.

Nieszczerzewska M. (2005), Miasta nie-miasta, „Kultura i Społeczeństwo” nr 1.

Paszkowski Z. (2011), Miasto idealne w perspektywie europejskiej i jego zwiazki z urbanistyka wspótczesną, Universitas, Kraków.

Shea B. (2008), Aerotropolis, „Crain's Detroit Business” vol. 24. 